Law \& Economics Working Papers

Law \& Economics Working Papers Archive:

2003-2009

University of Michigan Law School

Year 2007

\title{
Paying to Save: Tax Withholding and Asset Allocation among Low- and Moderate-Income Taxpayers
}

Michael S. Barr* Jane Dokko ${ }^{\dagger}$

*University of Michigan Law School, msbarr@umich.edu

${ }^{\dagger}$ Federal Reserve Board, jane.k.dokko@frb.gov

This paper is posted at University of Michigan Law School Scholarship Repository.

http://repository.law.umich.edu/law_econ_archive/art79 


\title{
Paying to Save: Tax Withholding and Asset Allocation Among Low- and Moderate-Income Taxpayers
}

\author{
Michael S. Barr and Jane K. Dokko* \\ University of Michigan and Federal Reserve Board
}

November 29, 2007

\begin{abstract}
We analyze the phenomenon that low- and moderate-income (LMI) tax filers exhibit a "preference for over-withholding" their taxes, a measure we derive from a unique set of questions administered in a dataset of 1,003 households, which we collected through the Survey Research Center at the University of Michigan. We argue that the relationship between their withholding preference and portfolio allocation across liquid and illiquid assets is consistent with models with present-biased preferences, and that individuals exhibit self-control problems when making their consumption and saving decisions. Our results support a model in which individuals use commitment devices to constrain their consumption. Using data on other tax-filing behaviors, we also show that mental accounting and loss aversion explanations for tax filers' "preference for over-withholding" are unlikely to explain the patterns in the data. Dynamic inconsistency among LMI tax filers has important implications for saving policies and for tax administration at large.
\end{abstract}

JEL Codes: C42, H2, H83, K34

\footnotetext{
${ }^{*}$ We would like to thank our project manager, Esther Ullman, our production manager, Sara Freeland, Terry Adams, the team at the Survey Research Center, and our Advisory Board, who worked together on sampling, survey design, and data collection. We are grateful to Chester Choi, Maria Dooner, and Robyn Konkel for invaluable research assistance. We also thank Ben Keys, Reuven Aviyonah, Kyle Logue, Rick Lempert, Jeff Kling, Jeff Liebman, Nada Eissa, Karen Dynan, numerous seminar participants at the University of Michigan, National Tax Association, IRS Research Conference, Federal Reserve Board, University of Illinois-Chicago, American Law and Economics Annual Conference, Harvard University's Seminar on Inequality and Social Policy, and the Conference on Empirical Legal Studies for helpful discussion and comments. The study received generous support from the Ford Foundation, Fannie Mae Foundation, MacArthur Foundation, Annie E. Casey Foundation, Mott Foundation, and Community Foundation of Southeastern Michigan, as well as the National Poverty Center, Center on Local, State, and Urban Policy, Provost, Vice President for Research, and Law School of the University of Michigan. The views, omissions, and errors in this paper are those of the authors and do not represent those of the Federal Reserve Board or the Federal Reserve System.
} 


\section{Introduction and Motivation}

In the United States, the Internal Revenue Service (IRS) collects taxes on earned income by requiring employers to remit a portion of the employees' paychecks as a prepayment of the taxes owed at the end of the year. If the amount prepaid is greater than the taxes owed, then the employee has over-withheld and is entitled to a tax refund in the amount of the difference. Over-withholding occurs at many income levels and is a common phenomenon among low- and moderate-income (LMI) taxpayers. Over 20 million LMI taxpayers file for approximately $\$ 35$ billion dollars in federal tax refunds and reduced tax liability (Internal Revenue Service, 2005). Given an average refund of over $\$ 1,700$ among LMI households, the economic implications of over-withholding are potentially quite large.

Economists typically view over-withholding as welfare-reducing and, therefore, undesirable as both an individual decision as well as a policy. Most obviously, the withholding system changes the timing of income from what it would be if individuals paid their taxes in a lump-sum fashion at the end of the year. From the perspective of the permanent income hypothesis (PIH), changes in the timing of income alone have no effect on individuals' ability to smooth consumption under an assumption about perfect capital markets. Because the U.S. Treasury does not pay interest on the amount over-withheld, however, the withholding system lowers the present value of lifetime income and makes individuals worse off with over-withholding. It is through this margin that the withholding system is welfare-reducing if the PIH provides an appropriate model of behavior. ${ }^{1}$ In most economic models, the payment of interest on the amount over-withheld is welfare-enhancing, ceteris paribus. $^{2}$

Whether LMI taxpayers share the canonical view of over-withholding is unclear. On the one hand, many LMI individuals would benefit from having their refund distributed evenly throughout the year, particularly in light of the credit constraints and high cost

\footnotetext{
${ }^{1}$ If, in addition, individuals cannot borrow or are credit-constrained, over-withholding exacerbates the liquidity constraints they experience during times of low income on both the extensive and intensive margins. That is, over-withholding, which results in a temporarily illiquid asset, crowds out precautionary saving.

${ }^{2}$ Technically speaking, if the U.S. Treasury were to pay interest on the amount over-withheld, individuals may not be better off since higher taxes would finance this endeavor.
} 
borrowing opportunities available to this group. Indeed, many LMI tax filers take out refund anticipation loans (RAL), and pay a non-trivial fee to a tax preparer, in order to expedite the receipt of a tax refund (Barr and Dokko, 2006). On the other hand, in experimental and non-experimental settings, individuals prefer increasing consumption profiles to flat or decreasing ones, even when the former correspond to lower present values than the latter (Loewenstein and Thaler, 1989; Loewenstein and Sicherman, 1991; Frank and Hutchens, 1993; Neumark, 1995). The explanation for this finding, particularly in the context of tax over-withholding, remains an open question.

The primary methodological challenge to identifying whether individuals want to overwithhold has been the lack of appropriate data. Inter alia, default rules, individuals' inertia, and existing tax administration rules militate against interpreting the actual occurrence of over-withholding, given by tax return data, as evidence that individuals want to over-withhold (Gale, 1998). In this paper, however, we provide a measure of taxpayers' "preference for over-withholding" using a unique question administered in the Detroit Area Household Financial Services (DAHFS) study, a dataset that we designed and collected through the Survey Research Center (SRC) at the University of Michigan. This question asks individuals to express whether they want to over-withhold their income in a hypothetical scenario in which they must choose the time profile of how to receive their income and pay their taxes. In a sample of LMI tax filers, $69 \%$ report that they want to over-withhold their income.

This unique question, combined with a rich set of covariates, allow us to systematically address alternative explanations for individuals' preference for non-smooth consumption profiles. These alternatives include individuals' loss aversion and mental accounting (Kahneman and Tversky, 1979; Thaler and Shefrin, 1981; Thaler, 1990), risk aversion, the possibility of negative personal discount rates (Mishkin, 1981; Courant, Gramlich, and Laitner, 1984; Loewenstein and Sicherman, 1991), status quo bias, and self-control problems related to dynamic inconsistency and the divergence between short- and long-term discount rates ( $\beta$ and $\delta$ in Laibson's (1997) notation). That a large majority of individuals express a pref- 
erence for over-withholding is not consistent with PIH or precautionary behavior. Instead, we conclude that dynamic inconsistency motivates certain types of individuals to constrain their consumption behavior through over-withholding.

This conclusion is based on a robust correlation between individuals' "preference for over-withholding" and their portfolio allocation across different types of liquid and illiquid financial instruments. We separate our sample of LMI tax filers into five portfolio allocation groups: those with no assets, one liquid asset, one illiquid asset, several but mainly liquid assets, and those with several but mainly illiquid assets. As we show, this portfolio allocation measure proxies for individuals' desire to limit their access to their savings as well as their (in)ability to save. The rich data on tax-filing behaviors and attitudes in our dataset permit an analysis of whether individuals' loss aversion, mental accounting, status quo bias, risk aversion, and negative personal discount rates are also related to their "preference for overwithholding." A subsequent section describes these data in further detail.

Section 2 of this paper expands upon the behavioral theories under which individuals choose rising or non-smooth consumption profiles over alternative profiles of equal or greater present value. We also outline our empirical framework in Section 2. Section 3 describes our unique dataset of LMI individuals, along with the detailed questions about tax filing in the survey. Section 4 describes the evidence on their withholding preferences vis-a-vis their asset portfolios and credit constraints. Section 5 concludes and presents the policy implications.

\section{Theoretical Background, Related Literature, and Empiri- cal Strategy}

With rich enough data, the myriad explanations for individuals' preference for rising or nonsmooth consumption profiles are empirically distinguishable. The approach of this paper is based on existing models that predict a relationship between portfolio allocation and wanting to over-withhold (Laibson, 1997; Laibson, Repetto, and Tobacman, 1998; O'Donoghue 
and Rabin, 1999; Laibson, Repetto, and Tobacman, 2000; Angeletos, Laibson, Repetto, Tobacman, and Weinberg, 2001). In these studies, individuals have present-biased preferences of the form:

$$
U_{t}=E_{t}\left[u\left(c_{t}\right)+\beta \sum_{\tau=1}^{T-t} \delta^{t} u\left(c_{t+\tau}\right)\right]
$$

where $u(\cdot)$ is a twice-differentiable, concave utility function, $c_{t}$ denotes consumption in period $t, \beta>0$, and $0 \leq \delta \leq 1$. The parameter $\beta$ reflects the individual's present-biasedness while $\delta$ is the time-consistent discount factor. ${ }^{3}$ Models with present-biased preferences suggest that those seeking to pre-commit, either to limit over-consumption or to overcome procrastination, will also want to over-withhold (Laibson, 1997; Laibson, Repetto, and Tobacman, 1998; O’Donoghue and Rabin, 1999; Laibson, Repetto, and Tobacman, 2000; Angeletos, Laibson, Repetto, Tobacman, and Weinberg, 2001).

To identify the savers who are seeking to pre-commit, we categorize tax filers into five asset allocation groups: non-savers, savers with only one liquid asset, savers with only one illiquid asset, savers with multiple but mainly liquid assets, and savers with multiple but mostly illiquid assets. As we will show, this categorization permits an identification of the savers who seemingly limit their access to their saving and those who have difficulty saving (perhaps due to procrastination). The theoretical prediction of existing models with present-biased preferences is testable by estimating the following relationship:

$$
o_{i}=\alpha+\sum_{g} \gamma_{g} p_{g i}+\phi f\left(X_{i}\right)+\epsilon_{i}
$$

where $o_{i}$ is an indicator for whether tax filer $i$ expresses a preference for over-withholding, $p_{g i}$ is an indicator for the tax filer's asset allocation group, $X_{i}$ is a vector of demographic and

\footnotetext{
${ }^{3}$ Many studies have used this present-biased lifetime utility function, including Phelps and Pollak (1968), Laibson (1997, 1998), Laibson, Repetto, and Tobacman (1998), and O'Donoghue and Rabin (1999). As these studies discuss, an attractive feature of formulating the lifetime utility function using the $\beta$ - $\delta$ discount factors is that the dynamically consistent individual is one for whom $\beta=1$. The basis for this type of utility function is that individuals' short-term discount factors are, in laboratory settings, much smaller than their long-term ones.
} 
socio-economic controls, $f(\cdot)$ is an arbitrary and flexible function of the control variables, and $\epsilon_{i}$ represents unobservable characteristics of tax filers that are potentially related to whether they express a preference for over-withholding and/or to their asset allocation group. The unobservables may include things like financial planning ability or a bias toward the status quo, to the extent that these are not captured by our proxy measures. We apply Ordinary Least Squares (OLS) to uncover the $\gamma_{g}$ coefficients, which are simply the regression-adjusted average likelihoods of wanting to over-withhold for the $g$ asset allocation groups. For convenience, we estimate (2) with a constant so the $\gamma_{g}$ 's represent the mean differences with respect to the group with no assets, and the estimate of $\alpha$ yields the percent who want to over-withhold among those with no assets.

In models of present-biased preferences, we expect to observe $\alpha>0$ and $\gamma_{g}$ 's of different magnitudes. ${ }^{4}$ In principle, the distribution of individuals across these asset allocation groups represents, among other things, their revealed preference for liquid and illiquid saving, which in turn depends on individuals' time preference, risk tolerance, and income volatility. In addition, these asset allocation groups may reflect other motivations for saving in one or multiple liquid and illiquid assets, such as dynamic inconsistency, "mental accounts", or loss aversion. Among the five groups we identify, we expect different preferences for overwithholding. We expect those with mostly liquid assets not to want over-withholding if their revealed preferences given by their asset allocation favor liquidity and they do not reveal difficulty with saving. We expect non-savers to be less likely to pre-commit to saving. If illiquid savers are more likely to restrain access to their savings, then we expect $\gamma_{g}$ to be larger for this group. At the same time, another group is also likely to want to over-withhold: procrastinators. Procrastinators, by definition, delay saving, and thus have difficulty accumulating assets. If procrastinators are more highly concentrated among those with only one asset, then we also expect this group to be more likely to express a preference for over-withholding to counteract their procrastination. Among those with only

\footnotetext{
${ }^{4}$ Without making strong assumptions about the magnitudes of $\beta$ and $\delta$ in (1), as well as the nature of the income process, it is difficult to predict an exact magnitude for $\alpha$ or $\gamma_{g}$ for the asset allocation groups under the present-biased model.
} 
one asset, there is no a priori way of assessing whether holders of a liquid or illiquid asset procrastinate more. Moreover, those with one asset are likely to be poorer, and poverty constrains one's ability to save, independent of one's preference for over-withholding. We thus defer the discussion about the interaction between using pre-commitment devices and procrastination to Section 4, where we present our results. In sum, we expect two groups to express a larger preference for over-withholding - those with illiquid assets and those with only one asset.

There are numerous challenges in exploiting the relationship between withholding preferences and asset allocation to detect dynamic inconsistency. Most obviously, there are many other factors related to both asset allocation and wanting to over-withhold. With the many variables in our rich dataset, we argue that we isolate the independent relationship between asset allocation and the preference to over-withhold. These control variables include measures such as race, education, and other demographic variables, as well as employment status, income, income volatility, having a credit card, and whether the sample member participates "often" in his/her household's financial decision-making. To be explicit, using these control variables does not isolate a "causal" effect of portfolio allocation for two reasons. First, the many unobservable (to the econometrician) determinants of portfolio allocation across liquid and illiquid assets makes specifying $f(\cdot)$, and thus isolating the exogenous variation in portfolio allocation, particularly difficult. Second, the independent variation in portfolio allocation, which proxies for a preference for liquidity, is not a well-identified cause in that it cannot be manipulated in an experimental or quasiexperimental sense (Holland, 1986; Rubin, 1986). However for our purposes, we are not interested in estimating a causal relationship between portfolio allocation and wanting to over-withhold. Rather, ascertaining whether LMI tax filers' behavior is consistent with models with present-biased preferences rests on observing a particular correlation between asset allocation and a preference for over-withholding.

Another important set of control variables include measures of risk tolerance and time preference, which are described further in the next section. Previous research emphasizes 
that these preference parameters may contribute to individuals choosing rising or nonsmooth consumption profiles when faced with future uncertainty (Mishkin, 1981; Courant, Gramlich, and Laitner, 1984; Loewenstein and Sicherman, 1991; Frank and Hutchens, 1993; Neumark, 1995). If individuals are risk-averse and tax liabilities are uncertain, overwithholding provides insurance against owing penalties to the IRS for the underpayment of taxes. Individuals who exhibit behavior consistent with negative discount rates may also want to over-withhold. To the extent that these preference parameters are omitted and are correlated with both portfolio allocation and withholding preferences, estimating (2) will result in biased estimates of $\gamma_{g}$ across the portfolio allocation groups. Hence, finding heterogeneity in $\gamma_{g}$ will not be informative of whether tax filers' behavior is consistent with models with present-biased preferences. To avoid this particular problem of inference due to these omitted variables, we attempt to control for both risk tolerance and time preference with survey measures also used in Barsky, Juster, Kimball, and Shapiro (1997). The next section describes these variables in greater detail.

We also explore whether "mental accounting" explains whether individuals want to overwithhold. An attractive feature of the dynamically inconsistent model with present-biased preferences is that it allows for a "mental accounting" framework (Thaler and Shefrin, 1981; Thaler, 1990). As Laibson $(1997,1998)$ shows, windfalls to liquid wealth result in different changes to consumption than windfalls to illiquid wealth, with present-biased individuals splurging more, given changes to liquid wealth. In this "mental accounting" framework, having a preference for over-withholding may represent a preference for receiving a liquid windfall upon receiving one's refund rather than for using over-withholding as a precommitment device. This distinction is a subtle one, and it is important to recognize that both motives are driven by a self-control problem and the inability to commit to a consumption plan. ${ }^{5}$ For this to affect our interpretation of the heterogeneity in the $\gamma_{g}$ 's as according

\footnotetext{
${ }^{5}$ More generally, the "mental accounting" framework holds the view that not all sources of income are the same and that different types of windfall gains result in different changes in consumption (Thaler, 1990). That is, the "mental accounting" framework need not be completely nested within models of dynamic inconsistency. Tax refunds may finance different types of consumption, such as durable goods purchases, if "mental accounting" plays a role in individuals decision-making. In addition, individuals may be loss averse
} 
with dynamically inconsistent behavior, the use of "mental accounts" must be correlated with the portfolio allocation groups, and the groups that want to over-withhold the most must also be the ones most likely to apply "mental accounting" rules. To distinguish these two stories, we present data on whether tax filers view their refunds as windfall gains and report whether they used their refunds to purchase durable goods. If we observe similarities in these outcomes across the portfolio allocation groups, then we can infer that it is unlikely for the heterogeneity in over-withholding preferences across the portfolio allocation groups to proxy for differences in mental accounting.

Similarly, for loss aversion to color our interpretation of the relationship between portfolio allocation and wanting to over-withhold, the groups that are most likely to want over-withholding must also be the most loss-averse. While we have no direct measure of loss aversion, using the sizes of their refunds, we are able to identify the tax filers who are more likely to owe tax liability. If loss aversion influences tax filers to want to overwithhold, then we may expect loss aversion to manifest more strongly among those with a higher probability of writing a check to the IRS. This group may then express a stronger preference for over-withholding. By studying the behavior of this sub-sample of tax filers, we may infer the importance of loss aversion. If, in addition, the relationship between portfolio allocation and wanting to over-withhold remains the same among the tax filers most likely to owe tax liability (as among all filers), then we may be reasonably confident that heterogeneity in loss aversion does not explain tax filers' preference for over-withholding.

To examine whether dynamic inconsistency manifests in other contexts, we relate other tax filing behaviors to the portfolio allocation groups. Upon filing their taxes, individuals choose how quickly to receive their refunds via check, direct deposit, or a refund anticipation loan (RAL). They must also confront how to allocate their refunds between consumption and saving (including paying down debt). When choosing how quickly to receive their refunds, present-biased individuals trade off the cost of having cash-in-hand today (with a RAL) against the value of accessing their money at a future date, which includes both

to the point that they will over-withhold their taxes to void having to write a check to the IRS. We defer a detailed discussion of these competing explanations to the next two sections. 
a larger net refund amount as well as the commitment value of illiquidity. Being offered a RAL provides an opportunity to unravel the commitment of over-withholding; however, present-biased individuals who value commitment may not take a RAL if the costs, which typically are associated with an APR ranging between $150 \%$ and 500\%, are too high. ${ }^{6}$ Thus, we examine the variation in RAL take-up to examine whether those who want to over-withhold more are more likely to purchase a RAL. Moreover, once the commitment is undone, present-biased individuals who take out RALs may be more likely to spend their tax refund than those who do not want to over-withhold.

\section{Data and Sample}

The data for this paper are from the Detroit Area Household Financial Services (DAHFS) study, a survey we designed. The Survey Research Center (SRC) at the University of Michigan administered the survey. The survey focuses on LMI individuals' experiences with formal and informal financial institutions, including their tax-filing experiences, and their socioeconomic characteristics. ${ }^{7}$ The final survey was programmed for computer-assisted, in-person interviewing. The final survey instrument is, on average, 76 minutes in length.

The sample members were selected based on a stratified random sample of the Detroit metropolitan area (Wayne, Oakland, and Macomb counties). We drew households from census tracts with median incomes that are 0-60 percent ("low"), 61-80 percent ("moderate"), and 81-120 percent ("middle") of the Detroit area's median household income of $\$ 49,057$. We over-sampled low- and moderate-income strata and under-sampled the middle one. Hence, households are more likely to be drawn from the low- and moderate-income strata. Stratum definitions do not, however, restrict the income levels of the households to fall within these ranges. ${ }^{8}$ Once we selected a household, the SRC randomly selected an

\footnotetext{
${ }^{6}$ There may be institutional reasons why present-biased individuals may not take out RALs. For instance, the unbanked are over twice as likely as the banked to take out a RAL (see Barr and Dokko (2006)).

${ }^{7}$ Because there is no such comprehensive survey about the financial services experiences and attitudes of LMI households, the questionnaire required extensive development, pretesting, and validation. Further details on this process or the survey instrument are available upon request.

${ }^{8}$ With sampling weights, our sample represents the population of Detroit metropolitan area residents
} 
adult to interview from that household (Kish, 1949). Our dataset thus generalizes to both the adult individuals and households living in census tracts with median incomes less than $120 \%$ of the Detroit area's median, and is therefore not representative of the US population.

The dataset consists of individuals who completed the interview between July 2005 and March 2006, with almost $90 \%$ of the interviews occurring before January 2006. We interviewed 1,003 households and attained a 65-percent response rate. Upon completion of the data collection, SRC constructed sampling weights that are inversely proportional to a respondent's probability of selection. ${ }^{9}$ All estimates reported in this paper are weighted, and all standard errors are "clustered" at the segment level to account for the intra-segment correlation across individuals.

The sub-sample studied in this paper consists of 938 respondents from the "low"- and "moderate"-income strata. Of these, 650 (69.3\%) respondents report they filed a tax return for 2004 or 2003. ${ }^{10}$ As seen in Table (3), many in this sample of LMI tax filers belong to socially disadvantaged groups. Sixty-six percent self-identify as black or African-American, and $26 \%$ have less education than a high school degree. Over two-thirds of the sample is female, which reflects that single female-headed households are more common than singlemale headed households in the LMI neighborhoods of the Detroit metropolitan area. Table (3) compares the DAHFS sample to the U.S. Census characteristics of the households from the "low"- and "moderate"-income census tracts in the Detroit metropolitan area. In terms of age and race, the DAHFS sample matches well the Census data. For sex, education, and marital status distributions, the DAHFS sample differs somewhat from the Census data but in ways consistent with the sampling design, which is sensitive to the greater presence of single female-headed households (who, on average, are less likely to be married and more likely to obtain post-secondary education).

Table (2) exhibits the exact wording of the relevant and unique questions administered

living in low-, moderate-, and middle-income census tracts.

${ }^{9}$ Details on the construction of sampling weights are available from the authors upon request.

${ }^{10}$ In the survey, if respondents did not file a tax return in 2004 , we asked about their tax filing experiences in 2003. If someone is a financially uninvolved spouse or a dependent, it is possible that they responded "no" to the question of whether s/he filed a tax return even though his/her household may have filed one. 
in the survey and studied in this paper. To all tax filers, we asked a question about their preference for the withholding of their tax payments. Based on whether they responded they would like more, less, or the same amount withheld relative to their current withholding pattern, we define the individuals who want to over-withhold their paycheck to be those who want more withholding or those who want the same level of withholding and received a refund in 2003 or $2004 .{ }^{11}$ We assume that individuals report they want to over-withhold if and only if they believe it to be welfare-enhancing relative to the alternative of not over-withholding (that is, perfectly or under-withholding).

To determine financial (i.e. non-housing, non-auto) portfolio allocation, we examine responses to a series of questions about the types of savings a respondent has. We asked each sample member whether s/he holds a range of formal (e.g. money market) and informal (e.g. money orders) assets. For respondents with more than one type of asset, we asked a follow-up question listed in Table (2) to identify their main asset. Based on these responses, including the number and liquidity of their assets, we classify tax filers into non-savers, savers with only one liquid asset, savers with only one illiquid asset, savers with multiple but mostly liquid assets, and savers with multiple but mostly illiquid assets. ${ }^{12}$ Liquid savings instruments include money not in a retirement plan (money market funds, government savings bonds, treasury bonds, CD's, mutual funds, stocks, bonds), money in a bank account, cash, money orders, checks, jewelry, gold, appliances, electronics, and the contents of a bank safe deposit box. ${ }^{13}$ Illiquid instruments are IRAs, private retirement an-

\footnotetext{
${ }^{11}$ It is indeed possible for someone to want less withholding than their current pattern but still want to over-withhold a smaller amount. The trade-offs in the income pattern of the question enable us to partly rule out this possibility. About half of the respondents who want less withheld receive refunds under $\$ 1200$, which means that their hypothetical refund (current refund less $\$ 1200$ ) would be less than or equal to zero. Thus, one can infer that they do not want to over-withhold. In addition, among those receiving refunds greater than $\$ 1200$, it may be either the case that some would prefer to over-withhold less than they currently do or to reduce their withholding further than the options given by the question, e.g. they would like to receive a paycheck that is $\$ 200$ larger than their current one with a tax refund that is $\$ 2400$ smaller. We thus feel that we have an under-estimate of those who would like to over-withhold.

${ }^{12}$ We exclude housing and automobiles when classifying the respondents' assets for three main reasons. First, practically speaking, due to the relative value of these physical (v. financial) assets, most everyone would be an illiquid saver (and there would thus be no variation to exploit). Second, houses and automobiles are different in that they have a substantial consumption value associated with them. Finally, we are interested in interpreting the heterogeneity in asset allocation as a revealed preference for liquidity. We believe that, given the first two reasons, including housing and automobiles would result in a noisier interpretation.

${ }^{13}$ We acknowledge that jewelry, gold, appliances, electronics, and the contents of a bank safe deposit box
} 
nuity accounts, pension, retirement plan, other tax-advantaged plans, real estate other than a primary residence, a business or farm, cash value in a life insurance policy, or withheld payroll taxes.

We use other unique variables from the survey to control for individual-specific characteristics that are correlated with portfolio allocation. Standard theoretical models of portfolio choice and saving behavior point toward income risk and volatility, risk aversion, time preference, and the relevance or importance of credit constraints. As the description in Table (2) shows, income risk is given by a self-assessment of how much a respondent's month-to-month income fluctuated during the year prior to the survey. ${ }^{14}$ The risk tolerance and time preference questions are similar to those in the Health and Retirement Survey (HRS) and discussed in Barsky, Juster, Kimball, and Shapiro (1997). Risk tolerance measures the probabilities at which a respondent is willing to choose a gamble with lifetime income over the certainty of his/her lifetime income. The time preference variables measure whether a respondent would rather pay for a $\$ 300$ appliance today or a series of higher amounts one year in the future. Barsky, Juster, Kimball, and Shapiro (1997) provide evidence that the survey measure of risk tolerance identifies individuals in the HRS who are more likely to engage in risky behaviors. Table (2) presents the exact wording of the risk tolerance and time preference questions.

\section{Results}

The data enable us to distinguish among competing explanations for individuals' preference for a rising or non-smooth income profile. We argue that the results suggest that dynamic inconsistency explains the heterogeneity in wanting to over-withhold across portfolio allocation groups (but not the level). Broadly speaking, individuals express a preference for

may not be liquid in the sense that there are non-trivial transactions costs associated with converting them to cash. The wording of the saving questions, however, do not permit us to separate the liquid aspects of these instruments from the illiquid (e.g. cash, jewelry or gold, appliances and electronics are treated as one category of assets).

${ }^{14}$ While the ideal measure of income risk would be of anticipated future income risk, the best available measure in the DAHFS study pertains to past income volatility. 
over-withholding and forced saving through the tax system.

Our bases for this finding are threefold: first, the types of assets held by those with a greater preference for over-withholding are consistent with the predictions of models with a present-biased individual. Second, this finding is independent of other factors that explain both how individuals save and whether they want to over-withhold their income, such as risk tolerance and time preference. Third, we find other tax filing behaviors to be consistent with dynamic inconsistency, but not models of loss aversion or mental accounting.

The results section proceeds as follows: first, we motivate the classification of tax filers into five asset allocation groups. Second, we show that the heterogeneity in preferences for over-withholding among these asset allocation groups is consistent with models with present-biased preferences. In the third section, we reject standard models as explanations for this preference by showing that the heterogeneity is not due to other factors, such as time preference or risk tolerance. Lastly, our findings allow us to show that loss aversion and mental accounting cannot explain the patterns we observe.

\subsection{Asset Allocation Groups}

The five asset allocation groups map to underlying differences in saving behavior and attitudes. As seen in the sample size in Table (5), there is substantial variation in the portfolio allocation decisions of LMI tax filers. While some have no financial assets, most have at least one financial asset. In other words, an overwhelming majority of LMI tax filers are able to accumulate at least one type of financial asset. The group with only one illiquid asset is the smallest. ${ }^{15}$ Tax filers with more than one but mostly illiquid financial assets comprise the largest group.

In Table (4), LMI tax filers' asset allocation across liquid and illiquid instruments reveals their behavior-constraining motives. Illiquid savers are 11 percentage points more likely than liquid savers to express that they use an illiquid asset to save because they find "it is not so easy to get to" their money. Furthermore, illiquid savers are 32 percentage points

\footnotetext{
${ }^{15}$ The modal asset is an IRA or other retirement account for this group. It is intriguing that this group has an illiquid asset but not a bank account.
} 
less likely to express that they use an illiquid asset because they find "it easy to get to their money." Table (4) illustrates that LMI tax filers use illiquid savings instruments for their constraining, or "lock box," features.

Also, there is suggestive evidence that portfolio allocation among LMI tax filers uncovers their "ability to save." The "ability to save" measures reported in Table (5) potentially reflect individuals' awareness of their tendencies to procrastinate or delay their saving, among other things. In Table (5), those with mainly illiquid assets or one liquid asset are most unable to save based on their self-assessments. Based on the point estimates, they are most likely to report that they feel unable to save for an anticipated major expense occurring five to 10 years in the future. Both of these groups are also most likely to be unable to earn enough income to meet their expenses during most or all months in the year prior to the survey interview.

Among those with one asset, the choice of the asset's liquidity need not necessarily reflect a preference for pre-commitment. Within this group, the ability to save over-rides their preference for illiquid assets and pre-commitment. Tax filers with one liquid asset are nearly 20 percentage points more likely not to contribute to their savings than the group with one illiquid asset. Also, the former is over 10 percentage points more likely to agree that it is difficult to resist the temptation to spend money (see Table (5)). For these reasons, in a model with a present-biased individual, this group will be more likely than those with one illiquid asset to want to over-withhold. Furthermore, tax filers with one illiquid asset are almost 10 percentage points more likely to have experienced a hardship in the year prior to the survey interview, which in turn is likely to lower their demand for illiquid savings. ${ }^{16}$

\footnotetext{
${ }^{16}$ We also examine behaviors related to self-control, such as gambling, buying lottery tickets, or having a drug-or alcohol-related problem. Unfortunately, more so than in Table (5), there is not enough precision in the data to identify which of the portfolio allocation groups is most or least likely to have these self-control problems. However noisy, the data consistently point to tax filers with mainly illiquid assets or one liquid asset as those most likely to exhibit self-control problems. Indeed, it may be the case that those with better self-control allow themselves to gamble or purchase lottery tickets for the consumption value of these activities.
} 


\subsection{Over-withholding Preferences and Asset Allocation}

The top row in Table (6) displays striking results on LMI individuals' withholding preferences. A large majority, or $69 \%$, of LMI individuals would prefer to over-withhold their paycheck and receive a refund, rather than under-withhold or withhold the "right" amount. In other words, many LMI individuals would like to use the federal withholding system in effect to save in a temporarily illiquid manner. This finding is particularly striking and, at first glance, seemingly inconsistent with the literature characterizing LMI individuals' high discount rates, binding liquidity constraints, and their general need and preference for cash-on-hand (Lewis, 1966, 1968; Lawrance, 1991; Bertrand, Mullainathan, and Shafir, 2004). Given that, on average, LMI tax filers receive a federal refund of around $\$ 1,700$, they are willing to forego roughly $\$ 45$ in interest in order to force themselves to save. ${ }^{17}$ We defer a detailed discussion of whether this trade-off is "reasonable" to the section describing the calibration exercise.

In addition, this finding presents a puzzle for the PIH, according to which over-withholding is necessarily welfare-reducing. If LMI tax filers were utility maximizing and making their saving decisions in line with the PIH, few, if any, would express that they want to save through the tax system. This finding is also inconsistent with precautionary motives since individuals are better off accumulating precautionary saving through interest-yielding means, rather than by over-withholding their income. In other words, there are better financial instruments to exploit than over-withholding one's income in building precautionary savings.

Consistent with model with present-biased preferences, there is heterogeneity in withholding preferences across different types of portfolio allocation in Table (6). ${ }^{18}$ Notably, $76 \%$ of mainly illiquid tax filers want to over-withhold, and $71 \%$ of those with one liquid asset want to do so. Put somewhat differently, mainly illiquid tax filers are 14 percentage

\footnotetext{
${ }^{17}$ This back of the envelope calculation assumes that the refund is distributed evenly each month and is compounded monthly with a $5 \%$ interest rate.

${ }^{18}$ The results of an F-test suggest rejecting the null hypothesis that the percentages are the same across portfolio allocation groups at the $5 \%$ significance level.
} 
points more likely than mainly liquid tax filers to express a preference for over-withholding. Given the relationship between the liquidity of the asset portfolio and wanting "lock-box" saving (see Table (4)), we find that, among those with more than one asset, those with a revealed preference for restricting one's access to savings are more likely to express a preference for over-withholding. Among those with only one asset, however, we find that the liquidity of assets does not correlate well with wanting to over-withhold. Based on the distribution of responses in Table (5), individuals with one liquid asset are more likely to feel they are unable to save, perhaps due to a self-control problem, and are thus more likely to value the forced saving aspect of over-withholding. Given these findings, we posit that among those with one asset, concerns about "ability to save" outweigh wanting an illiquid asset in explaining preferences for over-withholding.

\subsection{Standard Theories Explaining Wanting to Over-withhold}

The rich data in the DAHFS study permit empirically distinguishing among many competing theories explaining why LMI tax filers want to over-withhold, and why, more generally, they prefer rising or non-smooth consumption and income profiles. In this sub-section, we subject the first-order correlation between portfolio allocation and withholding preferences shown in Table (6) to alternative explanations for observing the patterns we do. Generally, the results in Table (7) suggest that rejecting PIH, precautionary, and other standard explanations is appropriate.

Under the PIH and the standard portfolio choice paradigm, neither illiquid nor liquid savers want to over-withhold and there is no heterogeneity in this preference across portfolio allocation groups. In each of the specifications in Table (7), an F-test rejects the null hypothesis that the propensity to want to over-withhold is the same across the portfolio allocation groups. Furthermore, based on Columns (2) and (3), we conclude that the pattern of withholding preferences is independent of the variation in demographic, economic, and financial characteristics across the portfolio allocation groups. In these columns, we control for demographic, economic, and financial characteristics that may differ across the portfolio 
allocation groups. ${ }^{19}$ We include a cubic in age to acknowledge life-cycle heterogeneity in portfolio allocation, along with other demographic variables. We use education dummies, as well as an indicator for how much the tax filer participates in financial decision-making to proxy for financial savviness. We also control for whether the tax filer is employed at the time of the survey interview, which proxies for whether someone has filled out a W-4 form. The inclusion of demographic, economic, and financial characteristics does not change the pattern of withholding preferences across the portfolio allocation groups, and the two groups that are most likely to want over-withholding include those with mainly illiquid assets or with one liquid asset.

Like the PIH and the standard portfolio choice model, over-withholding is welfarereducing in models of precautionary saving, and it is more so for those facing greater income volatility. The results in Columns (4) and (5) lead us to reject precautionary explanations for the heterogeneity in wanting to over-withhold across the portfolio allocation groups. Column (4) includes controls for past income volatility. If those with mostly liquid assets face more volatility in income and have a stronger distaste for over-withholding, then we would expect the differences in withholding preferences to equalize after controlling for income volatility. We find, however, that the differences persist and remain statistically significant. A cubic in annual household income distinguishes Column (5) from Column (4). In spite of the fact that income is highly correlated with the number and type of assets a tax filer holds, we continue to find a statistically significant relationship between asset allocation and wanting to over-withhold.

Beginning in Column (6), we include measures of risk tolerance and time preference as controls. The inclusion of these control variables sheds light on whether the heterogeneity in wanting to over-withhold across the portfolio allocation groups proxies for their differences

\footnotetext{
${ }^{19}$ Specifically, the demographic controls include a cubic in age, education, number of children, race sex, and marital status. Employment and financial variables include employment status, an indicator for whether respondent participates "a lot" in the household's financial decision-making, an indicator for whether the respondent sees himself as financially secure, an indicator for whether the respondent has a great deal of confidence in the people running banks and financial institutions, an indicator for having a credit card, and an indicator for using a paid tax preparer. The control for income includes a cubic in the household's annual income in 2004.
} 
in risk tolerance and time preference. If, for instance, those with mainly illiquid assets are more risk averse, then they may have a stronger preference for over-withholding to avoid owing taxes and penalties. Alternatively, if those with one liquid asset are more likely to have negative discount rates, then they may want to over-withhold more than the other portfolio allocation groups. ${ }^{20}$ Columns (6) to (8) allow us to reject these alternative scenarios.

Individuals may want to over-withhold if they fear being unable to anticipate the correct amount of their tax liability and being unable to pay their tax liability on top of any penalties for under-withholding, at the time of filing their taxes. To address this possibility, in Column (8), we include an indicator for whether it is easy for the tax filer to borrow $\$ 500$ as a measure of the extent to which liquidity constraints bind, in addition to whether someone has a credit card. In this most saturated model, we find that individuals with mostly illiquid assets remain about 13 percentage points more likely to want to over-withhold, and this difference is significant at the 5 percent significance level. Individuals with one liquid asset are also 10 percentage points more likely to want to over-withhold, but this difference is barely insignificant at the 10 percent level. This point estimate, however, is similar in magnitude to the one in Column (1).

Thus far, we have staked the claim that the relationship between individuals' portfolio allocation and withholding preferences is consistent with models with present-biased preferences but not with standard explanations. The basis for this claim is threefold. First, a large fraction of the DAHFS survey's LMI sample wants to over-withhold, and we believe that they would not respond in this manner unless they believed over-withholding to be welfare-enhancing (relative to under-withholding or exactly-withholding). In models of dynamic inconsistency, over-withholding and restraining one's choice set can be welfareenhancing. Second, we estimate a cross-sectional relationship between portfolio allocation

\footnotetext{
${ }^{20}$ In addition, controlling for risk tolerance and time preference suggests that portfolio allocation is correlated with wanting to over-withhold above and beyond what is implied by the PIH. If, for instance, illiquid assets are riskier, then the standard portfolio choice paradigm suggests that the relationship between asset allocation and withholding preference is driven by risk tolerance, with more risk tolerant (i.e. less risk averse) individuals holding more illiquid assets and wanting to hold more illiquid assets.
} 
and withholding preferences that is consistent with models with present-biased preferences. Finally, this estimated relationship is robust to the inclusion of a several control variables that, under alternative theories, ought to wipe away the relationship between portfolio allocation and withholding preference (see Table (7)).

\subsection{Behavioral-Economics Explanations for Wanting to Over-withhold}

Status quo bias, mental accounting rules, and loss aversion among individuals, rather than their dynamic inconsistency, may potentially explain the observed correlation between their portfolio decisions and their preference for over-withholding. If these alternative explanations are responsible for the greater propensity to want over-withholding among those with mainly illiquid assets and those with one liquid asset, then interpreting this result as indicating greater behavior-constraining motives among these two groups would be misleading. In this section, we argue that these alternative explanations cannot explain the patterns we observe in the relationship between portfolio allocation and wanting to over-withhold.

Columns (1) to (8) of Table (7) control for whether the tax filer received a refund in order to address the view that the heterogeneity in receiving a refund explains the variation in wanting to over-withhold. Put differently, using whether the tax filer received a refund as an additional control variable addresses the view that the status quo shapes individuals' preferences. If individuals who receive refunds do so because they like to over-withhold, and this phenomenon is correlated with portfolio allocation, then the explanation for individuals' preference for over-withholding is due to status quo bias. In each of Columns (1) to (8), we do indeed find that receiving a refund correlates well with wanting to over-withhold, and on average, those who get a refund are more likely to want to over-withhold than those who do not. We also find, however, that the differences in withholding preferences and portfolio allocation persist after controlling for whether the respondent receives a refund, and are therefore unlikely to be related to differences in the likelihood of refund receipt across the portfolio allocation groups. Individuals with mostly illiquid assets and those with one liquid asset are 13 and 11 percentage points more likely, respectively, than those with no assets to 
express a preference for over-withholding. We thus conclude that dynamically inconsistent behavior occurs independently of individuals' preference for the behavioral default.

Table (8) presents results to address whether "mental accounting" and loss aversion are better explanations than our interpretation of the relationship between wanting excess withholding and portfolio allocation. Based on the results in Columns (1) and (2), we believe that differences in "mental accounting" are unlikely to explain the heterogeneity in wanting excess withholding across the portfolio allocation groups. In Column (1) we find that, conditional on receiving a refund, $28 \%$ of tax filers report they view their refund as a windfall, which we define as survey respondents' agreeing with the statement "I feel like I won the lottery." ${ }^{21}$ Overall, we find that relatively few tax filers categorize their tax refunds as lottery earnings. ${ }^{22}$ Column (1) also shows the regression-adjusted differences in viewing their refund as a windfall across the portfolio allocation groups. While those with assets are generally less likely to think of their refund as windfall income than those without assets, there is no statistical difference in this "mental accounting" measure across the portfolio allocation groups. Similarly, the likelihood of purchasing a durable good, such as an appliance or car, with a tax refund is not statistically different across the portfolio allocation groups. With both of these "mental accounting" measures, the correlations in the data suggest that mental accounting is unlikely to explain the relationship between portfolio allocation and over-withholding preferences.

Given that the average refund size in this sample is roughly $\$ 1700$, in general, we do not find the loss aversion explanation for tax filers' preference for over-withholding particularly compelling. Individuals need only to over-withhold by $\$ 1$ in order to avoid having to write a check to the IRS. We provide additional evidence against the loss aversion explanation in Table (8). In Column (3), we report the relationship between wanting to overwithhold and portfolio allocation among the sub-sample of tax filers who receive a refund

\footnotetext{
${ }^{21}$ This "mental accounting" measure is by no means exhaustive of all the ways individuals may classify income. It may not entirely rule out that tax refunds are different from a regular paycheck, however, we can at a minimum distinguish whether tax refunds fall in the same mental account as lottery winnings.

${ }^{22}$ In addition, few tax filers feel that they are able to buy something frivolous upon receiving their tax refunds (results not shown). These results are available upon request.
} 
less than $\$ 1200$. Applying this cutoff identifies the tax filers who, by one measure, have the highest probabilities of incurring a tax liability if they were to withhold $\$ 100$ less each month. ${ }^{23}$ Among this sub-sample of tax filers, $55 \%$ want to over-withhold; contrary to the loss aversion prediction, they are less likely to want excess withholding than those receiving larger refunds. The top row of Column (3) suggests an inverse relationship between the likelihood of owing taxes at the time of filing and a preference for over-withholding, which is the opposite of what a model of loss aversion predicts. Furthermore, we again find that those with mainly illiquid assets or those with one liquid asset are the groups most likely to want excess withholding. They are 18 and 13 percentage points more likely to want to over-withhold than the group with no assets. These point estimates are well within a standard error of what we find in Table (7) so we do not believe that the likelihood of owing taxes at the time of filing, and thus loss aversion, affects our interpretation of of tax filers' preference for over-withholding. ${ }^{24}$

We acknowledge, however, that loss aversion can be an important reason for motivating some households to prefer over-withholding. Given the importance of framining in influencing indivudals' expressed preferencess (see Kahneman and Tversky (1979)), we designed the survey to include a reframing of the withholding question so as to introduce the concept of loss. In particular, holding total tax liability constant, we asked survey respondents who indicated that they wanted to withhold $\$ 100$ less each month and have a $\$ 1,200$ smaller refund at the end of the year whether they would still want to withhold $\$ 100$ less if they were to owe $\$ 1200$ more in taxes at the end of the year (see Table (2). Reframing the question in this way results in a 13 percentage point drop in the portion of tax filers who report that they want to withhold less than they currently do (from $19 \%$ to $6 \%$ ). This finding suggests that loss aversion may be an important motivator among those who would otherwise want less withholding. Among those who prefer over-withholding, however, for

\footnotetext{
${ }^{23}$ Note that the sample size drops to 312 , and if we were to use a smaller cut-off, the sample size would be even smaller.

${ }^{24}$ The estimated difference in their preference for over-withholding is much larger among the tax filers with one illiquid asset. The standard error on this estimate is so large, however, that we cannot distinguish it from what we estimate in Table (7).
} 
reasons discussed in the previous paragraph, loss aversion does not appear to explain the relationship between portfolio allocation and their preferences for over-withholding.

\subsection{Other Tax-Filing Behaviors}

We now turn to other aspects of tax-filing to demonstrate additional evidence also suggestive of the view that LMI individuals want to use the withholding system to commit and constrain their behavior.

Table (9) estimates the relationship between portfolio allocation and whether a tax filer spends all of his/her refund. Overall, about half of the tax filers who receive their refunds report they spent all of it (Barr and Dokko, 2006). Table (9) shows the heterogeneity in this estimate by portfolio allocation. Tax filers with mostly liquid assets, who are the least likely to want to over-withhold, are 16 percentage points less likely to spend all of their refund than are the other tax filers. Conversely, the tax filers who are most likely to want to over-withhold are just as likely to spend the entirety of their refund as those with one illiquid asset and those with no assets. Thus, when their commitment is undone at the time that they receive their tax refund, the tax filers wanting to constrain their behavior are more likely or equally likely to spend all of their refunds. This finding is robust to a variety of controls.

For most tax filers, "spending" their refund means increasing their net saving by paying down their debt or paying other bills. When these tax filers spend their refunds, on average, $80 \%$ of them use the money to pay down debt or other bills (Barr and Dokko, 2006). Table (10) shows that the mostly liquid tax filers are least likely both to spend the entirety of their refund and to pay debt or other bills. The mostly illiquid tax filers are nearly 10 percentage points more likely to spend all of their refund in order to pay their bills and other debt than the mainly liquid group. Among the tax filers with only one asset, both (liquid and illiquid) groups are equally likely to spend all of their refund to pay their bills and other debt. Overall, those who are more likely to want over-withholding are more or equally likely to spend all of their refunds to pay their bills or debt, despite their desire to 
pre-commit.

With this evidence, it is difficult to know whether their consumption would have been different had they not over-withheld. That is, we do not know whether the forced commitment constrained consumption or led to more borrowing. We know, however, that they spent enough to undo their forced saving, which is consistent with dynamically inconsistent behavior. Furthermore, this behavior is more prevalent among those who are more likely to want over-withholding.

Finally, Table (11) illustrates the differences in refund anticipation loan (RAL) usage by portfolio allocation type. Overall, $38 \%$ of tax filers took out a RAL, which is correlated with using a paid tax preparer. ${ }^{25}$ Interestingly, the two groups least likely to take out a RAL are the ones most likely to want over-withholding: mostly illiquid tax filers are 5 percentage points less likely to take out a RAL than mostly liquid tax filers. Those with one liquid asset are 15 percentage points less likely to take out a RAL than those with one illiquid asset. If the RAL take-up decision were simply one regarding whether to obtain the refund immediately rather than later, this finding would be inconsistent with models with present-biased preferences. Instead, we argue that the RAL decision is also about whether to unravel the commitment of over-withholding, at a non-trivial cost.

We find that the tax filers most likely to want the commitment to save through overwithholding are, in fact, less likely to pay to undo it. In effect, they choose to wait for the refund rather than paying for a RAL to unravel the commitment. This behavior is consistent with present-biased individuals valuing a commitment mechanism. Further work is needed to understand whether additional factors drive the RAL decision that differ across groups. For example, individuals without bank accounts must wait longer for their refund check, or those with one illiquid asset may have a more pressing need for liquidity. Thus, the institutional and economic benefits of taking a RAL may be higher for these groups than for those with mainly illiquid assets or with one liquid asset.

\footnotetext{
${ }^{25}$ One of the control variables in Table (11) is the likelihood of using a paid preparer, so we can rest assured that the heterogeneity is unlikely to be driven by differences in the use of a paid tax preparer.
} 


\subsection{Calibration Results}

In the DAHFS study, the average refund is nearly $\$ 1,700$, which corresponds to about $\$ 47$ in foregone interest if the refund were evenly distributed each month rather than dispersed as a lump-sum upon filing one's taxes. ${ }^{26}$ To assess whether this trade-off is a plausible one given present-biased preferences, we calibrate a simple model with quasi-hyperbolic discounting. The goals of the calibration exercise are threefold: first, we estimate the optimal level of over-withholding using values of $\beta$ and $\delta$ found in the experimental literature (Ainslie, 1992; Laibson, Repetto, and Tobacman, 1998; Angeletos, Laibson, Repetto, Tobacman, and Weinberg, 2001; Frederick, Loewenstein, and O'Donoghue, 2002; Shapiro, 2005). Second, for the optimal level of over-withholding, we find the associated willingness to pay for the commitment mechanism. Finally, we find values of $\beta$ and $\delta$ such that over-withholding $\$ 1,700$ leaves a dynamically inconsistent individual (weakly) better off than if she were to perfectly withhold her taxes. ${ }^{27}$

The results of the calibration derive from a utility maximization problem with the preferences in Equation (1) and with perfect capital markets. An individual chooses consumption in each month subject to an annual budget constraint. For a given level of annual income, over-withholding reduces the amount of cash-on-hand available in months one to 11, and shifts the cash-on-hand to month 12 . With an isoelastic intraperiod utility function, $u\left(c_{t}\right)=\frac{c_{t}^{1-\rho}}{1-\rho}$, and $\log$-utility arises when $\rho=1$. We use 0.996 as the value for $\delta$ and 0.958 as the value for $\beta$ (Laibson, Repetto, and Tobacman, 1998; Laibson, 1997, 1998). ${ }^{28}$ During the year, an individual has access to all of her annual income (cash-on-hand), except the amount over-withheld, which becomes available in the last period. In this highly stylized environment, with these parameter values for $\beta$ and $\delta$, this income process, and $\rho=1$, an individual with an annual after-tax income of $\$ 24,000$ finds $\$ 183$ as the optimal level of over-

\footnotetext{
${ }^{26}$ This foregone interest is $2.8 \%$ of the amount over-withheld at a $5 \%$ interest rate that is compounded monthly.

${ }^{27}$ The precise details of the calibration exercise are available upon request. Generally, we adapt the solution method in Shapiro (2005).

${ }^{28}$ The calibration takes the month as the unit of time, and these parameter values correspond to annualized values of $\delta$ and $\beta$ of approximately 0.95 and 0.60 , respectively, which correspond to commonly used values in the literature.
} 
withholding. ${ }^{29}$ This individual is willing to pay $\$ 8$, which is $4.4 \%$ of the optimal amount of over-withholding or $0.03 \%$ of her annual income, to have a commitment mechanism, relative to the regime without over-withholding.

For an over-withholding amount of $\$ 1,700$ to leave a quasi-hyperbolic discounter better off, she would need to be extremely present-biased, with $\beta$ equal to 0.81 and $\delta$ equal to 0.996. This monthly value for $\beta$ corresponds to an annualized short-term discount factor of 0.08, which is outside the range usually accepted in the literature (Ainslie, 1992; Frederick, Loewenstein, and O'Donoghue, 2002). Furthermore, for more reasonable values of $\beta$, an individual's annual income must be quite high if $\$ 1,700$ of over-withholding were to leave her (weakly) better off.

The calibration results suggest that the optimal level of over-withholding is low, and that over-withholding by $\$ 1,700$ is "excessive." That is, this amount is unlikely to be the result of a utility-maximizing decision in a highly stylized environment in which there are no costs (pecuniary or otherwise) to changing one's withholding pattern. In practice, there are significant costs to changing one's withholding pattern to match one's preference for the timing of income, such as tax administration rules and employer costs. In addition, the calibration exercise assumes that quasi-hyperbolic discounting is the sole reason for wanting a commitment mechanism against over-consumption, when in fact multiple motives are likely behind this preference. For example, status quo bias, mental accounting, and loss aversion may also contribute to our understanding of over-withholding. The results of the calibration exercise, however, are not inconsistent with our results, which show that dynamic inconsistency can independently explain the heterogeneity in wanting to over-withhold in the DAHFS study (but not the level).

\footnotetext{
${ }^{29}$ Indeed, with isoelastic utility, the optimal amount of over-withholding is a constant fraction of an individual's annual income.
} 


\section{Conclusion and Policy Implications}

Looking at a unique measure of individuals' "preference for over-withholding," we uncover a manifestation of the self-control problems LMI individuals confront when making their consumption and saving decisions. We find that a large majority of LMI tax filers want excess withholding, in spite of the canonical view that it is welfare-reducing. We further find that wanting to over-withhold correlates with portfolio allocation across liquid and illiquid assets. Tax filers with mainly illiquid assets or one liquid asset are between 10 and 13 percentage points more likely than other groups to want to over-withhold. We interpret this finding as suggesting that tax filers seek a pre-commitment device against the tendency to over-consume, as well as that the withholding system enables procrastinators to save. These results are consistent with the behavior of present-biased individuals who are dynamically inconsitent and seek commitment devices.

In this paper, we argue that LMI individuals' preferences for over-withholding relate to dynamic inconsistency independent of the "mental accounts" that individuals form or to their loss aversion and distaste for owing tax liability. When individuals' behavior is dynamically inconsistent, they value pre-commitment mechanisms, which suggests that illiquid savings plans tied to tax refunds may provide an opportunity for LMI individuals to build assets (Barr, 2004; Duflo, Gale, Liebman, Orszag, and Saez, 2005). In addition, other types of illiquid savings plans that are not focused solely on retirement may elicit higher take-up among LMI individuals. Individuals' behavior in the presence of mental accounting rules and loss aversion also emphasizes tying savings plans to tax refunds, but knowing that individuals are dynamically inconsistent highlights the importance of making these accounts illiquid (Thaler, 1994). Because the calibration results suggest that the optimal level of over-withholding is quite low relative to the size of the average refund, it remains an open question as to whether "excessive" over-withholding ought to be a desirable policy goal.

Researchers have argued that increasing withholding without altering tax liabilities may provide a way to encourage saving (Thaler, 1994). Dynamic inconsistency combined with a 
plethora of high-cost borrowing opportunities somewhat qualify this view. Although forced saving in an illiquid asset is valued by dynamically inconsistent individuals, we should weigh this welfare improvement against the temptation of high-cost borrowing opportunities such as payday loans, credit cards with high interest and fees, and refund anticipation or W-2 loans. ${ }^{30}$ Indeed, excessively large amounts of over-withholding may exacerbate dynamically inconsistent individuals' tendencies to incur high-cost debt. Additional research incorporating a dynamic structural model and simulations is necessary to better understand these trade-offs.

In addition to leading individuals to value pre-commitment devices, dynamic inconsistency also results in procrastination. We argue that tax filers with one liquid asset want to over-withhold more than other tax filers because of their relative inability to save. To the extent that procrastination contributes to an inability to save, providing LMI individuals with a simple menu of savings opportunities to lower the cognitive cost of saving may encourage this behavior. This simplicity necessarily entails de-mystifying the fee structure and minimum balance requirements, among other features, of savings and transaction accounts (Barr, 2004).

That tax filers want to over-withhold means they are willing to pay in order to save. Given an average refund of $\$ 1700$, a LMI tax filer is willing to forego $\$ 45$ in interest in order both to save in a temporarily illiquid asset as well as to restrict the availability of consumption opportunities. Aside from valuing present consumption more than consumption in the near future, there may be unobservable reasons why LMI individuals face pressures to consume more today. An important ethnographic finding is that LMI individuals often have others around them asking for financial help, which makes it more likely for them to consume out of cash-on-hand than if their income were illiquid (Caskey, cited in New York Times (4/1/2007)). Given our finding that LMI individuals are very willing to put away their money where neither they nor those around them can access it, we feel it is important to quantitatively distinguish this basis for present-biased preferences from the

\footnotetext{
${ }^{30}$ The W-2 loan delivers an amount based on an estimate of one's tax refund, where the estimate is derived from an individual's final pay stub.
} 
more traditional view. 


\section{References}

Ainslie, G. (1992): Picoeconomics: The Strategic Interaction of Successive Motivational States within the Person. Cambridge University Press, Cambridge, UK.

Angeletos, G.-M., D. Laibson, A. Repetto, J. Tobacman, and S. Weinberg (2001): "The Hyperbolic Consumption Model: Calibration, Simulation, and Empirical Evaluation," Journal of Economic Perspectives, 15(3), 47-68.

Barr, M. S. (2004): "Banking the Poor," Yale Journal on Regulation, 21(1), 121-237.

BARR, M. S., AND J. K. Dokko (2006): "Tax Filing Experiences and Withholding Preferences Among Low- and Moderate-Income Households: Preliminary Evidence from a New Survey," 2006 IRS Conference Proceedings, pp. 195-213.

Barsky, R. B., F. T. Juster, M. Kimball, and M. Shapiro (1997): "Preference Parameters and Behavioral Heterogeneity: An Experimental Approach in the Health and Retirement Study," Quarterly Journal of Economics, 112(2), 537-579.

Bertrand, M., S. Mullainathan, and E. Shafir (2004): "A Behavioral-Economics View of Poverty," American Economic Review Papers and Proceedings, 94(2), 419-423.

Carroll, C. D. (1997): "Buffer-Stock Saving and the Life Cycle/Permanent Income Hypothesis," Quarterly Journal of Economics, 112, 1-56.

Carroll, C. D., R. E. Hall, and S. P. Zeldes (1992): "The Buffer-Stock Theory of Saving: Some Microeconomic Evidence," Brookings Papers on Economic Activity, 1992(2), 61-156.

Caskey, J. P. (1994): Fringe Banking: Check-Cashing Outlets, Pawnshops, and the Poor. Russell Sage Foundation, New York.

Courant, P. N., E. Gramlich, and J. Laitner (1984): "A Dynamic Micro Estimate of the Life-Cycle Model," in Retirement and Economic Behavior, ed. by H. G. Aaron, and G. Burtless. Brookings Institute, Washington, D.C.

Deaton, A. (1991): "Saving and Liquidity Constraints," Econometrica, 59, 819-863.

Duflo, E., W. Gale, J. Liebman, P. Orszag, and E. Saez (2005): "Savings Incentives for Low- and Middle-Income Families: Evidence from a Field Experiment with H\&R Block," NBER Working Paper \#11680.

Frank, R. H., and R. M. Hutchens (1993): "Wages, Seniority, and the Demand for Rising Consumption Profiles," Journal of Economic Behavior and Organization, 21, 251276.

Frederick, S., G. Loewenstein, and T. O’Donoghue (2002): "Time Discounting and Time Preference: A Critical Review," Journal of Economic Literature, 40, 351-401.

Gale, W. G. (1998): "Comment: Self-Control and Saving for Retirement," Brookings Papers on Economic Activity, 1998(1), 177-185. 
Holland, P. W. (1986): "Statistics and Causal Inference," Journal of the American Statistical Association, 81(396), 945-960.

Internal Revenue Service (2005): "Statistics of Income," Available from http://www.irs.gov/taxstats/index.html.

Kahneman, D., and A. Tversky (1979): "Prospect Theory: An Analysis of Decision Under Risk," Econometrica, 47, 263-291.

KISH, L. (1949): "A Procedure for Objective Respondent Selection with the Household," Journal of the American Statistical Association, 44(247), 380-387.

Laibson, D. (1997): "Golden Eggs and Hyperbolic Discounting," Quarterly Journal of Economics, pp. 443-477.

(1998): "Live-Cycle Consumption and Hyperbolic Discount Functions," European Economic Review, 42, 861-871.

Laibson, D., A. Repetto, and J. Tobacman (1998): "Self-Control and Saving for Retirement," Brookings Papers on Economic Activity, 1998(1), 91-196.

(2000): “A Debt Puzzle," NBER Working Paper No. 7879.

Lawrance, E. C. (1991): "Poverty and the Rate of Time Preference: Evidence from Panel Data," Journal of Political Economy, 99(1), 54-77.

Lewis, O. (1966): La Vida: A Puerto Rican Family in the Culture of Poverty-San Juan and New York. Random House, New York.

- (1968): "The Culture of Poverty," in On Understanding Poverty, ed. by D. P. Moynihan. Basic Books, New York.

Loewenstein, G., And N. Sicherman (1991): "Do Workers Prefer Increasing Wage Profiles?," Journal of Labor Economics, 9(1), 67-84.

Loewenstein, G., And R. Thaler (1989): “Anomalies: Intertermporal Choice," Journal of Economic Perspectives, 3(4), 181-193.

Mishkin, F. S. (1981): "The Real Interest Rate: An Empirical Investigation," CarnegieRochester COnference Series on Public Policy, 15, 151-200.

Neumark, D. (1995): "Are Rising Earnings Profiles a Forced-Saving Mechanism?," Economic Journal, 105, 95-106.

New York Times (4/1/2007): THE WAY WE LIVE NOW: 4-01-07: IDEA LAB; Can Poor People Be Taught to Save? Available from http://www.nytimes.com/.

O'Donoghue, T., and M. Rabin (1999): "Doing It Now or Later," American Economic Review, 89(1), 103-124.

PAXson, C. (1990): "Borrowing Constraints and Portfolio Choice," Quarterly Journal of Economics, 105(2), 535-543. 
Phelps, E. S., and R. A. Pollak (1968): "On Second-Best National Saving and GameEquilibrium Growth," Review of Economic Studies, 35, 185-199.

Rubin, D. B. (1986): "Statistics and Causal Inference: Comment: Which Ifs Have Causal Answers," Journal of the American Statistical Association, 81(396), 961-962.

Samuelson, P. A. (1969): "Lifetime Portfolio Selection by Dynamic Stochastic Programming," Review of Economics and Statistics, 51, 239-246.

Shapiro, J. (2005): "Is There a Daily Discount Rate? Evidence from the Food Stamp Nutrition Cycle," Journal of Public Economics, 89, 303-325.

ThaleR, R. H. (1990): "Anomalies: Saving, Fungibility, and Mental Accounts," Journal of Economic Perspectives, 4(1), 193-205.

192.
(1994): "Psychology and Savings Policies," American Economic Review, 84, 186-

Thaler, R. H., And H. Shefrin (1981): “An Economic Theory of Self-Control," Journal of Political Economy, 89, 392-405.

Zeldes, S. P. (1989): "Consumption and Liquidity Constraints: An Empirical Investigation," Journal of Political Economy, 97(2), 305-346. 


\section{Tables}


Table 1: Theoretical Predictions About Portfolio Allocation and Withholding Preferences

\begin{tabular}{|c|c|c|c|}
\hline Model & $\begin{array}{l}\text { (1) Portfolio Allocation } \\
\text { Heterogeneity* }\end{array}$ & $\begin{array}{l}(2) \text { Over-Withholding } \\
\text { Preference** }^{* *}\end{array}$ & $\begin{array}{l}\text { Predicted Relationship Between } \\
\text { (1) and (2) }\end{array}$ \\
\hline $\begin{array}{l}\text { Std. Portfolio Choice } \\
\text { Paradigm (PIH) } \\
\text { (Samuelson, 1969) }\end{array}$ & $\begin{array}{l}\text { May reflect distribution } \\
\text { of risk preferences and } \\
\text { risk/return of assets }\end{array}$ & $\begin{array}{l}\text { Over-withholding is } \\
\text { welfare-reducing }\end{array}$ & $\begin{array}{l}\text { Liquid and illiquid savers do not } \\
\text { want to over-withhold }\end{array}$ \\
\hline $\begin{array}{l}\text { Precautionary Saving } \\
\text { (Zeldes, 1989; Deaton, } \\
\text { 1991; Carroll, Hall, and } \\
\text { Zeldes, 1992; Carroll, } \\
\text { 1997) }\end{array}$ & $\begin{array}{l}\text { May reflect distribution } \\
\text { of risk preferences and } \\
\text { risk/return of assets; Also } \\
\text { depends on precaution- } \\
\text { ary needs due to income } \\
\text { volatility and importance } \\
\text { of credit constraints }\end{array}$ & Same as PIH & $\begin{array}{l}\text { Liquid and illiquid savers do } \\
\text { not want to over-withhold; If } \\
\text { intensity of preferences observ- } \\
\text { able, individuals with high (ex- } \\
\text { pected) income volatility or } \\
\text { those with credit constraints ex- } \\
\text { press stronger distaste for over- } \\
\text { withholding; If savers facing } \\
\text { more volatility or credit con- } \\
\text { straints prefer liquid assets, then } \\
\text { liquid savers express stronger } \\
\text { distaste for over-withholding }\end{array}$ \\
\hline Paxson (1990) & $\begin{array}{l}\text { If borrowing limits are } \\
\text { exogenous, same as pre- } \\
\text { cautionary saving model; } \\
\text { If borrowing limits are } \\
\text { endogenous, heterogeneity } \\
\text { due to expectations about } \\
\text { whether future borrowing } \\
\text { constraints are likely to } \\
\text { bind }\end{array}$ & $\begin{array}{l}\text { Same as PIH since } \\
\text { amount over-withheld } \\
\text { cannot serve as collat- } \\
\text { eral }\end{array}$ & $\begin{array}{l}\text { Liquid and illiquid savers do } \\
\text { not want to over-withhold; If } \\
\text { intensity of preferences observ- } \\
\text { able and borrowing limits ex- } \\
\text { ogenous, same as precautionary } \\
\text { saving model; With endogenous } \\
\text { borrowing limits, savers facing } \\
\text { more volatility and credit con- } \\
\text { straints may prefer illiquid as- } \\
\text { sets because they provide collat- } \\
\text { eral for future borrowing so am- } \\
\text { biguous whether liquid or illiq- } \\
\text { uid savers express stronger dis- } \\
\text { taste for over-withholding }\end{array}$ \\
\hline $\begin{array}{l}\text { Present-Biased Prefer- } \\
\text { ences (Laibson, 1997; } \\
\text { Laibson, Repetto, } \\
\text { and Tobacman, 1998; } \\
\text { O'Donoghue and Ra- } \\
\text { bin, 1999; Angeletos, } \\
\text { Laibson, Repetto, To- } \\
\text { bacman, and Weinberg, } \\
\text { 2001) }\end{array}$ & $\begin{array}{l}\text { Reflects heterogeneity in } \\
\text { short-term impatience, in- } \\
\text { come volatility, and impor- } \\
\text { tance of credit constraints; } \\
\text { Default rules of liquid and } \\
\text { illiquid savings accounts } \\
\text { also determine how indi- } \\
\text { viduals allocate their assets }\end{array}$ & $\begin{array}{l}\text { Over-withholding pro- } \\
\text { vides a commitment } \\
\text { technology that can be } \\
\text { welfare-enhancing; De- } \\
\text { fault rules of withhold- } \\
\text { ing may provide easy } \\
\text { way to save }\end{array}$ & $\begin{array}{l}\text { Illiquid savers are more likely } \\
\text { to want over-withholding, as are } \\
\text { procrastinators }\end{array}$ \\
\hline
\end{tabular}

* "Portfolio Allocation Heterogeneity" means the extent and intensity to which individuals save across liquid and illiquid assets.

** "Withholding Preference" means that individuals, if given the opportunity to choose how to receive their income and pay their taxes during the year, would explicitly choose to over-withhold. 
Table 2: Description of Survey Questions and Variable Definition

\begin{tabular}{|c|c|}
\hline $\begin{array}{l}\text { Survey Question or Vari- } \\
\text { able }\end{array}$ & Description or Definition \\
\hline \multirow[t]{2}{*}{ Withholding Preference } & $\begin{array}{l}\text { Next we have a question about how people think about tax refunds. In this } \\
\text { question, you have a choice of how you get your income. The total amount } \\
\text { of your tax refund or money owed will be the same for each option. But you } \\
\text { can choose whether you get the money spread out over the year or all at the } \\
\text { end. I will read the question and your answer choices ... For this question, } \\
\text { please assume that you receive a regular paycheck from an employer. Which } \\
\text { of the following describes how you would like to receive your income? A } \\
\text { paycheck that is } \$ 100 \text { smaller each month than your current one with a tax } \\
\text { refund that is } \$ 1200 \text { larger at the end of the year; A paycheck that is the } \\
\text { same as your current one with no additional refund and no need to pay any } \\
\text { additional taxes at the end of the year; A paycheck that is } \$ 100 \text { larger each } \\
\text { month than your current one with a tax refund that is } \$ 1200 \text { smaller at the } \\
\text { end of the year? }\end{array}$ \\
\hline & $\begin{array}{l}\text { Would you want a paycheck that is } \$ 100 \text { larger each month than your } \\
\text { current one if you owed } \$ 1200 \text { more in taxes at the end of the year? }\end{array}$ \\
\hline $\begin{array}{l}\text { Main Non-housing Sav- } \\
\text { ings Instrument }\end{array}$ & $\begin{array}{l}\text { You said that you (and other members of your household) keep money in } \\
<<\text { List }>>\text {. In which of these did you keep most of your savings? }\end{array}$ \\
\hline Income Volatility & $\begin{array}{l}\text { Thinking back over the last } 12 \text { months, has your month-to-month income } \\
\text { gone up over the year, gone down over the year, has it gone up and down } \\
\text { a little, gone up and down a lot, or has it stayed about the same? }\end{array}$ \\
\hline \multirow[t]{2}{*}{ Borrowing $\$ 500$ Is Easy } & $\begin{array}{l}\text { If you needed to borrow } \$ 500 \text { for three months, is there some person (or } \\
\text { place) you could borrow it from? Where would you go first? }\end{array}$ \\
\hline & $\begin{array}{l}\text { This variable takes on a value of "1" if the respondent feels they can turn } \\
\text { to a friend, payday lender, or a credit card to borrow } \$ 500 \text {. }\end{array}$ \\
\hline Liquid Saving & $\begin{array}{l}\text { Money market funds, government savings bonds, treasury bonds or CDs } \\
\text { not in a retirement plan; Mutual funds, stocks or bonds not in a retirement } \\
\text { plan; Bank account; Bank safe deposit box; Money orders or checks; Cash, } \\
\text { jewelry or gold, appliances or electronics }\end{array}$ \\
\hline Illiquid Saving & $\begin{array}{l}\text { IRAs, private retirement annuities, or a pension or retirement plan from } \\
\text { employer; Other tax-advantaged savings plan not in retirement plan; Real } \\
\text { estate other than primary residence; Business or farm; Cash value in life } \\
\text { insurance policy; Withheld payroll taxes }\end{array}$ \\
\hline $\begin{array}{l}\text { Risk Tolerance and Time } \\
\text { Preference }\end{array}$ & $\begin{array}{l}\text { These questions are similar to the risk tolerance and time preference mea- } \\
\text { sures in the PSID and HRS. See Barsky, Juster, Kimball, and Shapiro } \\
\text { (1997) for further details. }\end{array}$ \\
\hline
\end{tabular}


Table 3: Summary Statistics for Sample of Low- and Moderate-Income Tax Filers (Standard Errors in Parentheses)

\begin{tabular}{|c|c|c|c|}
\hline & All Tax Filers & Full Sample & Detroit Metro $^{+}$ \\
\hline Age & $\begin{array}{c}42.9 \\
(1.04)\end{array}$ & $\begin{array}{c}43.5 \\
(1.00)\end{array}$ & 43.7 \\
\hline$\%$ Black & $\begin{array}{c}.655 \\
(.053)\end{array}$ & $\begin{array}{c}.686 \\
(.047)\end{array}$ & .623 \\
\hline$\%$ Female & $\begin{array}{c}.667 \\
(.021)\end{array}$ & $\begin{array}{c}.662 \\
(.016)\end{array}$ & .532 \\
\hline Less than HS & $\begin{array}{c}.254 \\
(.022)\end{array}$ & $\begin{array}{c}.294 \\
(.021)\end{array}$ & .322 \\
\hline HS Diploma or GED & $\begin{array}{c}.196 \\
(.019)\end{array}$ & $\begin{array}{c}.229 \\
(.019)\end{array}$ & .318 \\
\hline More than HS & $\begin{array}{c}.546 \\
(.027)\end{array}$ & $\begin{array}{c}.470 \\
(.022)\end{array}$ & .360 \\
\hline$\%$ Married & $\begin{array}{c}.249 \\
(.023)\end{array}$ & $\begin{array}{c}.196 \\
(.019)\end{array}$ & .368 \\
\hline$\%$ Receive Refund & $\begin{array}{l}.812 \\
(.02)\end{array}$ & $\begin{array}{c}\text { NA } \\
-\end{array}$ & $\begin{array}{c}\text { NA } \\
-\end{array}$ \\
\hline Average Refund (cond'l) & $\begin{array}{c}1,671 \\
(86)\end{array}$ & $\begin{array}{c}\text { NA } \\
-\end{array}$ & $\begin{array}{c}\text { NA } \\
-\end{array}$ \\
\hline \% Received RAL (cond'l) & $\begin{array}{c}.381 \\
(.024)\end{array}$ & $\begin{array}{c}\text { NA } \\
-\end{array}$ & $\begin{array}{c}\text { NA } \\
-\end{array}$ \\
\hline Participates Often in Financial Decisions & $\begin{array}{c}.76 \\
(.021)\end{array}$ & $\begin{array}{c}.750 \\
(.016)\end{array}$ & $\begin{array}{c}\text { NA } \\
-\end{array}$ \\
\hline Feels Financially Secure & $\begin{array}{c}.273 \\
(.024)\end{array}$ & $\begin{array}{c}.270 \\
(.018)\end{array}$ & $\begin{array}{c}\text { NA } \\
-\end{array}$ \\
\hline Sample Size & 650 & 965 & 384 \\
\hline
\end{tabular}

+ Statistics for the Detroit Metropolitan area (Wayne, Macomb, and Oakland counties) are obtained from the U.S. Census's FactFinder. To facilitate comparison with the DAHFS study, the Census statistics are obtained from census tract-level summary data for tracts with median incomes under $80 \%$ of the tri-county median of $\$ 49,051$. 
Table 4: Do Individuals Have Self-Control Problems? Evidence on "Lock-Box" Saving and Frequency of Adding to Savings (Standard Errors in Parentheses)

\begin{tabular}{l|cc}
\hline & Illiquid Savers & Liquid Savers \\
\hline $\begin{array}{l}\text { Responds "yes" to "Do you keep your savings in } \\
<<>>\text { because you find it helpful that it is not so }\end{array}$ & $58.5 \%$ & $47.8 \%$ \\
easy to get your money?" & $(2.6)$ & $(2.7)$ \\
& $34.9 \%$ & $66.7 \%$ \\
$\begin{array}{l}\text { Responds "yes" to "Do you keep your savings in } \\
<<>>\text { because you find it easy to get to your money, } \\
\text { if you need to?" }\end{array}$ & $(3.5)$ & \\
& & \\
\hline Sample Size & 223 & 297 \\
\hline
\end{tabular}

${ }^{*}$ Asked in reference to the sample member's main (or only) savings instrument.

Source: Detroit Area Household Financial Services Study. Sample includes respondents living in "low"- and "moderate"-income census tracts who filed a tax return in 2003 or 2004. 
Table 5: Measures of "Ability to Save" (Standard Errors in Parentheses)

\begin{tabular}{|c|c|c|c|c|c|}
\hline & Mostly Illiquid & Mostly Liquid & Has 1 Illiquid & Has 1 Liquid & No Assets \\
\hline \multirow{2}{*}{$\begin{array}{l}\text { Responds "yes" to "Do you } \\
\text { expect to face any major ex- } \\
\text { pense in the next } 5 \text { - } 10 \text { years } \\
\text { for which you are currently } \\
\text { unable to save?" }\end{array}$} & $37.5 \%$ & $37.2 \%$ & $34.7 \%$ & $44.5 \%$ & NA \\
\hline & $(3.7)$ & $(4.6)$ & (10.4) & (6.5) & - \\
\hline \multirow{2}{*}{$\begin{array}{l}\text { Income does not cover ex- } \\
\text { penses most or all months }\end{array}$} & $16.1 \%$ & $14.2 \%$ & $14.9 \%$ & $24.3 \%$ & $25.3 \%$ \\
\hline & $(2.4)$ & $(4.3)$ & $(6.0)$ & $(4.7)$ & $(3.7)$ \\
\hline \multirow{2}{*}{$\begin{array}{l}\text { In previous year, con- } \\
\text { tributed to savings "once or } \\
\text { twice" or never }\end{array}$} & $32.8 \%$ & $29.6 \%$ & $46.5 \%$ & $64.0 \%$ & NA \\
\hline & $(3.8)$ & $(4.1)$ & $(11.2)$ & (4.4) & - \\
\hline \multirow{2}{*}{$\begin{array}{l}\text { Agrees that "it is hard to re- } \\
\text { sist the temptation to spend } \\
\text { money" }\end{array}$} & $33 \%$ & $35.6 \%$ & $31.7 \%$ & $44.6 \%$ & \\
\hline & $(3.8)$ & $(4.2)$ & $(7.8)$ & $(5.0)$ & - \\
\hline \multirow{2}{*}{$\begin{array}{l}\% \text { Experiencing hardships in } \\
\text { previous year* }\end{array}$} & $40.2 \%$ & $42.6 \%$ & $52.4 \%$ & $44.4 \%$ & $57.2 \%$ \\
\hline & $(3.3)$ & $(4.1)$ & $(8.2)$ & $(4.6)$ & $(4.7)$ \\
\hline Sample Size & 185 & 180 & 38 & 117 & 130 \\
\hline
\end{tabular}

* Measures of hardships include experiencing a major illness, food insufficiency, eviction, bankruptcy, and having the phone or utilities shut off in the year prior to the survey.

** Asset amounts include the value of physical assets.

Source: Detroit Area Household Financial Services Study. Sample includes respondents living in "low"- and "moderate"-income census tracts who filed a tax return in 2003 or 2004.

Notes: "Mostly (Il)liquid" is an indicator for whether the respondent's non-housing, non-auto assets are mostly (il)liquid. "Has 1 (Il)liquid" is an indicator for whether the respondent has only 1 type of (il)liquid saving. Standard errors are clustered at the segment level. 
Table 6: Withholding Preference by Portfolio Allocation Group (Standard Errors in Parentheses)

\begin{tabular}{|c|c|c|c|c|c|c|}
\hline & All & Mostly Illiquid & Mostly Liquid & H1I $^{*}$ & $\mathrm{H}_{1} \mathrm{~L}^{* *}$ & No Assets \\
\hline \multirow{3}{*}{$\begin{array}{l}\% \text { that report they } \\
\text { prefer to over-withhold } \\
\text { paycheck rather than } \\
\text { under-withhold or } \\
\text { exactly-withhold }\end{array}$} & .685 & .761 & .623 & .599 & .713 & .618 \\
\hline & $(.027)$ & $(.037)$ & $(.048)$ & $(.073)$ & $(.047)$ & $(.045)$ \\
\hline & - & \multicolumn{5}{|c|}{ F-statistic: 3.43 , p-value: 0.0128} \\
\hline Sample Size & 650 & 220 & 145 & 38 & 117 & 130 \\
\hline
\end{tabular}

* H1I stands for "Has 1 Illiquid."

** H1L stands for "Has 1 Liquid."

The F-statistic and p-value correspond to a test of equality of the percentages. The F-statistic is distributed with 4 numerator and 70 denominator degrees of freedom. Standard errors are clustered at the segment level. 
Table 7: Do Individuals Constrain Their Behavior? Relationship Between Withholding Preference and Non-Housing, Non-Auto Asset Allocation (Standard Errors in Parentheses)

\begin{tabular}{|c|c|c|c|c|c|c|c|c|}
\hline & \multicolumn{8}{|c|}{ Dependent variable is "wants to over-withhold" } \\
\hline & $(1)$ & $(2)$ & $(3)$ & $(4)$ & $(5)$ & $(6)$ & $(7)$ & $(8)$ \\
\hline \multirow[t]{2}{*}{ Mostly Illiquid } & $.126^{* * *}$ & $.136^{* * *}$ & $.158^{* * *}$ & $.148^{* * *}$ & $.129^{* *}$ & $.149^{* * *}$ & $13^{* *}$ & $.131^{* *}$ \\
\hline & $(.044)$ & $(.048)$ & $(.051)$ & $(.055)$ & $(.057)$ & $(.055)$ & $(.056)$ & $(.058)$ \\
\hline \multirow[t]{2}{*}{ Mostly Liquid } & .019 & .024 & .044 & .033 & .02 & .031 & .019 & .021 \\
\hline & $(.055)$ & $(.059)$ & $(.058)$ & $(.06)$ & $(.061)$ & $(.061)$ & $(.061)$ & $(.06)$ \\
\hline \multirow[t]{2}{*}{ Has 1 Illiquid } & -.051 & -.037 & -.038 & -.053 & -.054 & -.045 & -.047 & -.048 \\
\hline & $(.083)$ & $(.081)$ & $(.08)$ & $(.078)$ & $(.078)$ & $(.078)$ & $(.077)$ & $(.077)$ \\
\hline \multirow[t]{2}{*}{ Has 1 Liquid } & $.106^{*}$ & $.139^{* *}$ & $.14^{* *}$ & $.113^{*}$ & $.115^{*}$ & .096 & .099 & .1 \\
\hline & $(.055)$ & $(.057)$ & $(.056)$ & $(.06)$ & $(.06)$ & $(.063)$ & $(.062)$ & $(.063)$ \\
\hline F-statistic & 2.957 & 3.059 & 3.187 & 2.805 & 2.579 & 2.641 & 2.34 & 2.303 \\
\hline (p-value) & $(.0256)$ & $(.0221)$ & $(.0183)$ & $(.0321)$ & $(.0447)$ & $(.0408)$ & $(.0634)$ & $(.0669)$ \\
\hline \multicolumn{9}{|l|}{ Controls: } \\
\hline Demographics? & No & Yes & Yes & Yes & Yes & Yes & Yes & Yes \\
\hline $\begin{array}{l}\text { Employment \& Finan- } \\
\text { cial Variables? }\end{array}$ & No & No & Yes & Yes & Yes & Yes & Yes & Yes \\
\hline Income Volatility? & No & No & No & Yes & Yes & Yes & Yes & Yes \\
\hline HH Income? & No & No & No & No & Yes & No & Yes & Yes \\
\hline Risk Tolerance? & No & No & No & No & No & Yes & Yes & Yes \\
\hline Time Preference? & No & No & No & No & No & Yes & Yes & Yes \\
\hline $\begin{array}{l}\text { Borrowing } \$ 500 \text { is } \\
\text { Easy? }\end{array}$ & No & No & No & No & No & No & No & Yes \\
\hline Gets Refund & Yes & Yes & Yes & Yes & Yes & Yes & Yes & Yes \\
\hline
\end{tabular}

Source: Detroit Area Household Financial Services Study. Sample includes respondents living in "low"- and "moderate"-income census tracts who filed a tax return in 2003 or 2004

Notes: "Mostly (Il)liquid" is an indicator for whether the respondent's non-housing, non-auto assets are mostly (il)liquid. "Has 1 (Il)liquid" is an indicator for whether the respondent has only 1 type of (il)liquid saving. The reference group thus consists of respondents who report they have no assets. Demographic controls include a cubic in age, education, number of children, race sex, and marital status. Employment and financial variables include employment status, an indicator for whether respondent participates "a lot" in the household's financial decision-making, an indicator for whether the respondent sees himself as financially secure, an indicator for whether the respondent has a great deal of confidence in the people running banks and financial institutions, an indicator for having a credit card, and an indicator for using a paid tax preparer. The control for income includes a cubic in the household's annual income in 2004. All estimates are weighted and obtained from a linear probability model. Standard errors are clustered at the segment level. See text for further descriptions of the variables.

* denotes statistical significance at the $10 \%$ level, two-tailed test.

** denotes statistical significance at the $5 \%$ level, two-tailed test.

*** denotes statistical significance at the $1 \%$ level, two-tailed test. 
Table 8: Rejecting Mental Accounting and Loss Aversion Explanations for Wanting to Over-withhold (Standard Errors in Parentheses)

\begin{tabular}{|c|c|c|c|}
\hline & $\begin{array}{c}\text { Refund is "Windfall" } \\
\text { (1) }\end{array}$ & $\begin{array}{c}\text { Dependent Variable } \\
\text { Buys Durable Good } \\
(2)\end{array}$ & $\begin{array}{l}\text { Wants to Over-withhold } \\
(3)\end{array}$ \\
\hline Overall \% & $28 \%^{+}$ & $33 \%^{+}$ & $55 \%$ \\
\hline No Assets \% & $43 \%^{+}$ & $27 \%^{+}$ & $62 \%$ \\
\hline Mostly Illiquid & $\begin{array}{l}-.076 \\
(.062)\end{array}$ & $\begin{array}{l}.118^{*} \\
(.065)\end{array}$ & $\begin{array}{l}.183^{*} \\
(.098)\end{array}$ \\
\hline Mostly Liquid & $\begin{array}{l}-.003 \\
(.064)\end{array}$ & $\begin{array}{c}.094 \\
(.058)\end{array}$ & $\begin{array}{c}.001 \\
(.106)\end{array}$ \\
\hline Has 1 Illiquid & $\begin{array}{c}-.139^{*} \\
(.076)\end{array}$ & $\begin{array}{c}.113 \\
(.092)\end{array}$ & $\begin{array}{l}.124 \\
(.151)\end{array}$ \\
\hline Has 1 Liquid & $\begin{array}{l}-.037 \\
(.053)\end{array}$ & $\begin{array}{l}.097^{*} \\
(.055)\end{array}$ & $\begin{array}{l}.127 \\
(.104) \\
\end{array}$ \\
\hline All Controls? & Yes & Yes & Yes \\
\hline Sample & All & All & Refund $\leq \$ 1200$ \\
\hline Sample Size & 650 & 650 & 312 \\
\hline
\end{tabular}

+ This percent is computed among those receiving a refund.

Source: Detroit Area Household Financial Services Study. Sample includes respondents living in "low"- and "moderate"-income census tracts who filed a tax return in 2003 or 2004.

Notes: "Mostly (Il)liquid" is an indicator for whether the respondent's non-housing, non-auto assets are mostly (il)liquid. "Has 1 (Il)liquid" is an indicator for whether the respondent has only 1 type of (il)liquid saving. The reference group thus consists of respondents who report they have no assets. Demographic controls include a cubic in age, education, number of children, race sex, and marital status. Employment and financial variables include employment status, an indicator for whether respondent participates "a lot" in the household's financial decision-making, an indicator for whether the respondent sees himself as financially secure, an indicator for whether the respondent has a great deal of confidence in the people running banks and financial institutions, an indicator for having a credit card, and an indicator for using a paid tax preparer. The control for income includes a cubic in the household's annual income in 2004. All estimates are weighted and obtained from a linear probability model. Standard errors are clustered at the segment level. See text for further descriptions of the variables.

* denotes statistical significance at the $10 \%$ level, two-tailed test.

** denotes statistical significance at the $5 \%$ level, two-tailed test.

*** denotes statistical significance at the $1 \%$ level, two-tailed test. 
Table 9: Relationship Between Spending All of Tax Refund and Non-Housing, Non-Auto Asset Allocation (Standard Errors in Parentheses)

\begin{tabular}{|c|c|c|c|c|c|c|c|c|}
\hline & \multicolumn{8}{|c|}{ Dependent variable is "spends all" } \\
\hline & (1) & $(2)$ & $(3)$ & $(4)$ & $(5)$ & $(6)$ & $(7)$ & $(8)$ \\
\hline \multirow[t]{2}{*}{ Mostly Illiquid } & $-.118^{* *}$ & -.078 & -.06 & -.057 & -.059 & -.061 & -.065 & -.07 \\
\hline & $(.057)$ & $(.072)$ & $(.07)$ & $(.071)$ & $(.071)$ & $(.069)$ & $(.07)$ & $(.07)$ \\
\hline \multirow[t]{2}{*}{ Mostly Liquid } & $-.185^{* * *}$ & $-.156^{* *}$ & $-.141^{* *}$ & $-.136^{* *}$ & $-.138^{* *}$ & $-.149^{* *}$ & $-.153^{* *}$ & $-.159^{* *}$ \\
\hline & $(.058)$ & $(.065)$ & $(.063)$ & $(.063)$ & $(.065)$ & $(.062)$ & $(.064)$ & $(.064)$ \\
\hline \multirow[t]{2}{*}{ Has 1 Illiquid } & .057 & .066 & .073 & .087 & .087 & .082 & .083 & .084 \\
\hline & $(.092)$ & $(.095)$ & $(.092)$ & $(.091)$ & $(.092)$ & $(.092)$ & $(.094)$ & $(.094)$ \\
\hline \multirow[t]{2}{*}{ Has 1 Liquid } & -.039 & -.028 & -.024 & -.018 & -.017 & -.005 & -.004 & -.006 \\
\hline & $(.059)$ & $(.064)$ & $(.062)$ & $(.062)$ & $(.062)$ & $(.06)$ & $(.06)$ & $(.061)$ \\
\hline F-Statistic & 3.758 & 2.743 & 2.284 & 2.305 & 2.163 & 2.629 & 2.51 & 2.686 \\
\hline (p-value) & $(.0079)$ & $(.0351)$ & $(.0688)$ & $(.0668)$ & $(.082)$ & $(.0416)$ & $(.0495)$ & $(.0382)$ \\
\hline \multicolumn{9}{|l|}{ Controls: } \\
\hline Demographics? & No & Yes & Yes & Yes & Yes & Yes & Yes & Yes \\
\hline $\begin{array}{l}\text { Employment \& Finan- } \\
\text { cial Variables? }\end{array}$ & No & No & Yes & Yes & Yes & Yes & Yes & Yes \\
\hline Income Volatility? & No & No & No & Yes & Yes & Yes & Yes & Yes \\
\hline HH Income? & No & No & No & No & Yes & No & Yes & Yes \\
\hline Risk Tolerance? & No & No & No & No & No & Yes & Yes & Yes \\
\hline Time Preference? & No & No & No & No & No & Yes & Yes & Yes \\
\hline $\begin{array}{l}\text { Borrowing } \$ 500 \text { is } \\
\text { Easy? }\end{array}$ & No & No & No & No & No & No & No & Yes \\
\hline Gets Refund & Yes & Yes & Yes & Yes & Yes & Yes & Yes & Yes \\
\hline
\end{tabular}

Source: Detroit Area Household Financial Services Study. Sample includes respondents living in "low"- and "moderate"-income census tracts who filed a tax return in 2003 or 2004.

Notes: "Mostly (Il)liquid" is an indicator for whether the respondent's non-housing, non-auto assets are mostly (il)liquid. "Has 1 (Il)liquid" is an indicator for whether the respondent has only 1 type of (il)liquid saving. The reference group thus consists of respondents who report they have no assets. Demographic controls include a cubic in age, education, number of children, race sex, and marital status. Employment and financial variables include employment status, an indicator for whether respondent participates "a lot" in the household's financial decision-making, an indicator for whether the respondent sees himself as financially secure, an indicator for whether the respondent has a great deal of confidence in the people running banks and financial institutions, an indicator for having a credit card, and an indicator for using a paid tax preparer. The control for income includes a cubic in the household's annual income in 2004. All estimates are weighted and obtained from a linear probability model. Standard errors are clustered at the segment level. See text for further descriptions of the variables.

* denotes statistical significance at the $10 \%$ level, two-tailed test.

** denotes statistical significance at the $5 \%$ level, two-tailed test.

*** denotes statistical significance at the $1 \%$ level, two-tailed test. 
Table 10: Relationship Between Paying Debt (and Spending All of Refund) and NonHousing, Non-Auto Asset Allocation (Standard Errors in Parentheses)

\begin{tabular}{l|cccccccc}
\hline & \multicolumn{7}{|c}{ Dependent variable is "pays debt" } & \\
& $(1)$ & $(2)$ & $(3)$ & $(4)$ & $(5)$ & $(6)$ & $(7)$ & $(8)$ \\
\hline Mostly Illiquid & $-.144^{* * *}$ & -.108 & -.1 & -.096 & $-.107^{*}$ & -.094 & -.107 & -.108 \\
Mostly Liquid & $(.055)$ & $(.066)$ & $(.065)$ & $(.065)$ & $(.065)$ & $(.065)$ & $(.066)$ & $(.066)$ \\
& $-.216^{* * *}$ & $-.192^{* * *}$ & $-.182^{* * *}$ & $-.177^{* * *}$ & $-.186^{* * *}$ & $-.185^{* * *}$ & $-.196^{* * *}$ & $-.198^{* * *}$ \\
Has 1 Illiquid & $(.052)$ & $(.06)$ & $(.057)$ & $(.055)$ & $(.057)$ & $(.055)$ & $(.057)$ & $(.057)$ \\
& .026 & .029 & .026 & .039 & .041 & .048 & .05 & .05 \\
Has 1 Liquid & $(.093)$ & $(.096)$ & $(.097)$ & $(.095)$ & $(.096)$ & $(.095)$ & $(.096)$ & $(.096)$ \\
& -.033 & -.021 & -.021 & -.016 & -.014 & -.004 & 0 & -.001 \\
& $(.058)$ & $(.06)$ & $(.058)$ & $(.056)$ & $(.057)$ & $(.054)$ & $(.055)$ & $(.055)$ \\
\hline F-statistic & 6.274 & 4.637 & 4.067 & 3.948 & 3.935 & 4.704 & 4.799 & 4.836 \\
(p-value) & $(.0002)$ & $(.0022)$ & $(.0051)$ & $(.006)$ & $(.0061)$ & $(.002)$ & $(.0018)$ & $(.0017)$ \\
\hline Controls: & & & & & & & & \\
& & & & & & & & \\
Demographics? & No & Yes & Yes & Yes & Yes & Yes & Yes & Yes \\
Employment \& Financial & No & No & Yes & Yes & Yes & Yes & Yes & Yes \\
Variables? & & & & & & & & \\
Income Volatility? & No & No & No & Yes & Yes & Yes & Yes & Yes \\
HH Income? & No & No & No & No & Yes & No & Yes & Yes \\
Risk Tolerance? & No & No & No & No & No & Yes & Yes & Yes \\
Time Preference? & No & No & No & No & No & Yes & Yes & Yes \\
Borrowing \$500 is Easy? & No & No & No & No & No & No & No & Yes \\
Gets Refund & Yes & Yes & Yes & Yes & Yes & Yes & Yes & Yes \\
& & & & & & & & \\
\hline So & & & & & &
\end{tabular}

Source: Detroit Area Household Financial Services Study. Sample includes respondents living in "low"- and "moderate"-income census tracts who filed a tax return in 2003 or 2004.

Notes: "Mostly (Il)liquid" is an indicator for whether the respondent's non-housing, non-auto assets are mostly (il)liquid. "Has 1 (Il)liquid" is an indicator for whether the respondent has only 1 type of (il)liquid saving. The reference group thus consists of respondents who report they have no assets. Demographic controls include a cubic in age, education, number of children, race sex, and marital status. Employment and financial variables include employment status, an indicator for whether respondent participates "a lot" in the household's financial decision-making, an indicator for whether the respondent sees himself as financially secure, an indicator for whether the respondent has a great deal of confidence in the people running banks and financial institutions, an indicator for having a credit card, and an indicator for using a paid tax preparer. The control for income includes a cubic in the household's annual income in 2004. All estimates are weighted and obtained from a linear probability model. Standard errors are clustered at the segment level. See text for further descriptions of the variables.

* denotes statistical significance at the $10 \%$ level, two-tailed test.

** denotes statistical significance at the $5 \%$ level, two-tailed test.

*** denotes statistical significance at the $1 \%$ level, two-tailed test. 
Table 11: Relationship Between Taking a Refund Anticipation Loan and Non-Housing, Non-Auto Asset Allocation (Standard Errors in Parentheses)

\begin{tabular}{l|cccccccc}
\hline & \multicolumn{7}{|c}{ Dependent variable is "takes RAL" } & \\
& $(1)$ & $(2)$ & $(3)$ & $(4)$ & $(5)$ & $(6)$ & $(7)$ & $(8)$ \\
\hline Mostly Illiquid & $-.182^{* * *}$ & $-.187^{* * *}$ & $-.118^{* *}$ & $-.122^{* *}$ & $-.116^{* *}$ & $-.124^{* *}$ & $-.117^{* *}$ & $-.113^{* *}$ \\
Mostly Liquid & $(.046)$ & $(.053)$ & $(.053)$ & $(.055)$ & $(.055)$ & $(.051)$ & $(.052)$ & $(.053)$ \\
& $-.132^{* *}$ & $-.124^{* *}$ & -.052 & -.055 & -.044 & -.067 & -.055 & -.049 \\
Has 1 Illiquid & $(.055)$ & $(.055)$ & $(.052)$ & $(.055)$ & $(.056)$ & $(.052)$ & $(.052)$ & $(.055)$ \\
& .044 & .017 & -.015 & -.017 & -.017 & -.012 & -.011 & -.012 \\
Has 1 Liquid & $(.09)$ & $(.085)$ & $(.083)$ & $(.088)$ & $(.09)$ & $(.086)$ & $(.088)$ & $(.087)$ \\
& $-.211^{* * *}$ & $-.187^{* * *}$ & $-.162^{* * *}$ & $-.162^{* * *}$ & $-.165^{* * *}$ & $-.168^{* * *}$ & $-.171^{* * *}$ & $-.169^{* * *}$ \\
& $(.05)$ & $(.047)$ & $(.045)$ & $(.048)$ & $(.048)$ & $(.048)$ & $(.049)$ & $(.049)$ \\
\hline F-statistic & 8.538 & 8.032 & 4.874 & 4.656 & 4.827 & 5.018 & 4.955 & 4.964 \\
(p-value) & $(0)$ & $(0)$ & $(.0016)$ & $(.0022)$ & $(.0017)$ & $(.0013)$ & $(.0014)$ & $(.0014)$ \\
\hline Controls: & & & & & & & & \\
& & & & & & & & \\
Demographics? & No & Yes & Yes & Yes & Yes & Yes & Yes & Yes \\
Employment \& Financial & No & No & Yes & Yes & Yes & Yes & Yes & Yes \\
Variables? & & & & & & & & \\
Income Volatility? & No & No & No & Yes & Yes & Yes & Yes & Yes \\
HH Income? & No & No & No & No & Yes & No & Yes & Yes \\
Risk Tolerance? & No & No & No & No & No & Yes & Yes & Yes \\
Time Preference? & No & No & No & No & No & Yes & Yes & Yes \\
Borrowing $\$ 500$ is Easy? & No & No & No & No & No & No & No & Yes \\
Gets Refund & Yes & Yes & Yes & Yes & Yes & Yes & Yes & Yes \\
& & & & & & & & \\
\hline Sos & & & & & &
\end{tabular}

Source: Detroit Area Household Financial Services Study. Sample includes respondents living in "low"- and "moderate"-income census tracts who filed a tax return in 2003 or 2004.

Notes: "Mostly (Il)liquid" is an indicator for whether the respondent's non-housing, non-auto assets are mostly (il)liquid. "Has 1 (Il)liquid" is an indicator for whether the respondent has only 1 type of (il)liquid saving. The reference group thus consists of respondents who report they have no assets. Demographic controls include a cubic in age, education, number of children, race sex, and marital status. Employment and financial variables include employment status, an indicator for whether respondent participates "a lot" in the household's financial decision-making, an indicator for whether the respondent sees himself as financially secure, an indicator for whether the respondent has a great deal of confidence in the people running banks and financial institutions, an indicator for having a credit card, and an indicator for using a paid tax preparer. The control for income includes a cubic in the household's annual income in 2004. All estimates are weighted and obtained from a linear probability model. Standard errors are clustered at the segment level. See text for further descriptions of the variables.

* denotes statistical significance at the $10 \%$ level, two-tailed test.

** denotes statistical significance at the $5 \%$ level, two-tailed test.

*** denotes statistical significance at the $1 \%$ level, two-tailed test. 